\title{
Mayfly Diversity in the Brazilian Tropical Headwaters of Serra do Cipó
}

\author{
Michael Goulart and Marcos Callisto* \\ Universidade Federal de Minas Gerais; ICB; Departamento de Biologia Geral; Laboratório de Ecologia de Bentos; \\ Av. Antônio Carlos, 6627; C. P. 486; 30161-970; callisto@icb.ufmg.br; mgoulart@icb.ufmg.br; Belo Horizonte - \\ $M G$ - Brasil
}

\begin{abstract}
The objectives of this study were to evaluate spatial and seasonal distribution, assemblage structure and substrate associations of mayfly nymphs in five lotic ecosystems in the headwaters of the Doce River and São Francisco River watersheds, Brazil. Samples were taken in 24 sampling stations during rainy and dry seasons in 1998. In total, 7,066 organisms were collected, belonging to 27 genera and 6 families of Ephemeroptera. The dominant taxa were Americabaetis, Paracloeodes, Leptohyphes and Hagenulus. During the rainy period, the São Francisco River watershed showed higher taxonomic richness, diversity and evenness, while in the dry period, the taxonomic richness was higher in Doce River watershed. No significant differences were found in the taxonomic richness, diversity, evenness and density of mayfly assemblages between the two studied sampling periods. The results suggested that the diversity of the mayfly assemblages in tropical headwaters of Serra do Cipó would be probably due to ecosystem and watershed characteristics.
\end{abstract}

Key words: Ephemeroptera, habitat diversity, substrate association, conservation, river ecology

\section{INTRODUCTION}

Lotic ecosystems offer a wide variety of conditions and habitats from the source to the mouth. Invertebrate assemblages are associated with particular types of rivers, which differ mainly on the type of water (e. g., bright, white, black), physical and chemical parameters, trophic level, river order, and their distribution are associated with variations on water current and substrate type (Allan, 1995; Ward et al., 1995).

The ecology of aquatic insect communities in Brazil has received little attention, despite their assumed importance in the organic matter transformation and energy flow of ecosystems (Callisto and Esteves, 1995), and their possible use as bioindicators of water quality (Alba-Tercedor, 1996; Marques and Barbosa, 2001) and ecosystem health (Galdean et al., 2000; Callisto et al., 2001a). Ecological studies about mayflies are still scarce in the tropics, with few concerning distribution, diversity and assemblage structure (Ferreira and Froehlich, 1992; Froehlich and Oliveira, 1997; Oliveira and Froehlich, 1997; Bispo and Oliveira, 1998).

Mayflies are a small group of primitive aquatic insects containing approximately 4,000 species in 300 genera, distributed all over the world, except for the poles and oceanic islands (Dominguez et al., 2001). Their abundance and distribution, regarding the zoogeographical limitation and abiotic features are determined mainly by

\footnotetext{
* Author for correspondence
} 
temperature, substrate type, water quality and flow velocity (Brittain, 1982). They occur in a wide variety of lotic and lentic water habitats, with the greatest diversity being found in $2^{\text {nd }}$ and $3^{\text {rd }}$ order streams (Edmunds and Waltz, 1998).

The Ephemeroptera are a conspicuous and diverse group in the sediment and aquatic macrophytes in lotic ecosystems of Serra do Cipó, and often constitutes the dominant group in the macroinvertebrates communities (Galdean et al., 1999, 2000, 2001). The lotic ecosystems of Serra do Cipó belong to two of the most important catchments in Brazil: Doce and São Francisco rivers. Within these two watersheds, some regions are in nearly "pristine" conditions (e.g., Indaiá and Capão da Mata streams, located within the Serra do Cipó National Park), while other regions have been affected by human activities to varying degrees (e. g., Cipó, Peixe and Preto do Itambé rivers) (Galdean et al., 2000).

The Doce River watershed is in the southeastern part of Brazil, between the states of Minas Gerais and Espírito Santo, with a drainage area of 83,400 $\mathrm{km}^{2}$. The human population is about 2.8 million in 163 municipal districts (FEAM, 1990). The São Francisco River is considered as the "dorsal spine" of the northeastern region, due to its influence in the socio-economic systems of the drained regions (Governo Federal, 1997). During its course of 3,161 km, it flows through Minas Gerais, Bahia, Pernambuco, Sergipe and Alagoas states, disemboguing in the Atlantic Ocean and forming a $670,000 \mathrm{~km}^{2}$ watershed (IBGE, 2001).

The main goals of this study were to evaluate the spatial and seasonal distribution, assemblage structure and substrate associations of mayfly nymphs in five lotic ecosystems of Serra do Cipó, in the headwaters of the Doce River and São Francisco River watersheds, Minas Gerais State, southeast Brazil. Based on this, the following questions were proposed: 1) Are there differences in the diversity, composition and total density of mayfly assemblages between the Doce river and São Francisco river watersheds? 2) Does the seasonality (rainy and dry periods) influence the diversity and total density values of these assemblages? 3) Do mayfly nymphs show specific preferences for the type of substrate? 4) Which are the main factors governing mayfly diversity?

\section{STUDY AREA}

Serra do Cipó is located in the central part of the Minas Gerais State $\left(19^{\circ}-20^{\circ} \mathrm{S} ; 43^{\circ}-44^{\circ} \mathrm{W}\right)$, presenting vegetation composed by savanna (locally called as "cerrado") in the lower altitudes up to 1,000 a.s.l., rupestrian fields at the highest portions (above 1,000 $\mathrm{m}$ ) and riparian forest in the humid valleys along the rivers. The typical soil type in the region is the latosoil, deep and with low fertility (Giulietti et al., 1987). The climate is classified as Cwb (Köppen), with rainy summers (October-March) and dry winters (AprilSeptember), and an annual median of precipitation about $1500 \mathrm{~mm}$ (Galvão and Nimer, 1965). The mean annual temperatures oscillate between $17.0^{\circ}$ and $18.5^{\circ} \mathrm{C}$ and the mean precipitation between 1,450 and $1,800 \mathrm{~mm} /$ year (CETEC, 1982).

The studied ecosystems were Indaiá Stream, Peixe and Preto do Itambé rivers (in the headwaters of the Doce River watershed); Capão da Mata stream and Cipó River (in the headwaters of the São Francisco River watershed).

\section{MATERIALS AND METHODS}

Samples were collected in the dry and rainy seasons of 1998 in all studied ecosystems using kick nets $\left(1 \mathrm{~m}^{2}, 0.250 \mathrm{~mm}\right.$ mesh), and immediately fixed with $10 \%$ formalin, except in the Capão da Mata stream and in Peixe River in the Sobrado Farm locality, collected only in the dry period, and Indaiá Stream, collected only in the rainy period. In the laboratory, the samples were washed on $0.250 \mathrm{~mm}$ sieves, sorted and identified under a stereomicroscope (40x) using the available literature (Dominguez et al. 1992; Dominguez and Pescador, 1994; Dominguez et al., 2001; LugoOrtiz and McCafferty, 1995; 1996a; 1996b; 1996c; Peters, 1971). The organisms were preserved in $70 \%$ ethanol and deposited in the Reference Collection of Benthic Macroinvertebrates, Institute of Biological Sciences, Federal University of Minas Gerais, Brazil.

The number of samples for each ecosystem was determined according to the diversity of substrates in almost $10 \mathrm{~m}$ section of each river reach, totaling 24 samples, being 8 in the rainy period and 6 in the dry period, in the Doce River watershed; and 4 in the rainy period and 6 in the dry period in the São Francisco River watershed. The sampled 
stations, with the respective substrates, river reaches, sampling periods and watersheds are summarized in Table 1.

The following physical and chemical parameters were measured in situ with a multiprobe Horiba: temperature $\left({ }^{\circ} \mathrm{C}\right), \mathrm{pH}$, electrical conductivity $(\mu \mathrm{S} / \mathrm{cm})$ and dissolved oxygen $(\mathrm{mg} / \mathrm{L})$. Water samples were collected in the sub-surface for the determination of the total Phosphorous and total Nitrogen, $\mathrm{PO}_{4}^{-}, \mathrm{NO}_{3}^{-}, \mathrm{NO}_{2}^{-}, \mathrm{NH}_{4}^{+}$, and soluble reactive silica, according to Golterman et al. (1978) and Mackereth et al. (1978). Total alkalinity was determined in the laboratory by the Gran method, modified by Carmouze (1994).

The Shannon-Wiener diversity and Evenness (Pielou) indexes (as proposed by Magurran, 1991), along with taxonomic richness were estimated for each sample in both sampling periods. Unpaired ttests and Mann-Whitney $U$ test were performed in order to evaluate significant differences in the taxonomic richness, H' Shannon-Wiener diversity index, Pielou evenness index and total density of mayfly nymphs, between the Doce river watershed and the São Francisco river watershed and between the sampling periods.

Table 1 - Sampled substrates and respective river reaches. *IS= Indaiá Stream; PC= Peixe River, confluence with Preto do Itambé River; PS= Peixe River in Sobrado Farm locality; PR= Preto do Itambé River; CM=Capão da Mata Stream; CC= Cipó River in the Chácara Farm locality; CS= Cipó River in Santana do Riacho municipality.

\begin{tabular}{|c|c|c|}
\hline Sample & Sampled Substrates and Ecosystems & \\
\hline$\# 1 \mathrm{~A}$ & Gravel and fine sediments & IS \\
\hline \#1B & Banks of Andraeae and Eriocaulaceae & IS \\
\hline \#2A & Deposit of fine detritus & $\mathrm{PC}$ \\
\hline \#2B & Leaves and branches of riparian vegetation & $\mathrm{PC}$ \\
\hline$\# 2 \mathrm{C}$ & Leaf litter/debris & $\mathrm{PC}$ \\
\hline \#3A & Stones withperiphytic algae & PS \\
\hline \#3B & Submerged angiosperms & PS \\
\hline \#4A & Deposit of fine detritus & PR \\
\hline \#4B & Leaves and branches of riparian vegetation & PR \\
\hline \#4C & Submerged angiosperms & PR \\
\hline \#5A & Leaves and branches of riparian vegetation & $\mathrm{CC}$ \\
\hline \#5B & Gravel and fine sediments & $\mathrm{CC}$ \\
\hline \#6A & Pebbles and gravel & CS \\
\hline \#6B & Leaves and branches of riparian vegetation & $\mathrm{CS}$ \\
\hline \#7A & Leaf litter/debris & $\mathrm{CM}$ \\
\hline \#7B & Deposit of fine detritus & $\mathrm{CM}$ \\
\hline \#7C & Bathrachospermum sp. (Algae) tufts & $\mathrm{CM}$ \\
\hline
\end{tabular}

\section{RESULTS}

\section{Abiotic features}

The studied ecosystems presented black waters (e. g., Indaiá and Capão da Mata streams) and bright waters (e. g., Cipó, Peixe and Preto do Itambé rivers). The waters were well oxygenated, ranging from $5.11 \mathrm{mg} / \mathrm{L}$ up to $9.85 \mathrm{mg} / \mathrm{L}$ in the Doce river watershed, while in the São Francisco river watershed, it ranged from $5.23 \mathrm{mg} / \mathrm{L}$ up to 7.33 $\mathrm{mg} / \mathrm{L}$. The electrical conductivity values were lower in the Doce river watershed, attaining values below $20.0 \mu \mathrm{S} / \mathrm{cm}$, while in the São Francisco river watershed the electrical conductivity values reached $45.10 \pm 31.54 \mu \mathrm{S} / \mathrm{cm}$ in the rainy period. The $\mathrm{pH}$ were predominantly slightly acid $(5.18 \pm$ $0.04)$ to neutral $(7.08 \pm 0.30)$, and the temperature recorded was higher and more constant for the Doce River watershed (minimum $21.17{ }^{\circ} \mathrm{C}$ and maximum $28.35{ }^{\circ} \mathrm{C}$ ). In the São Francisco watershed rivers, temperature ranged from 11.57 to $18.52{ }^{\circ} \mathrm{C}$ (Table 2).

Soluble reactive phosphorus concentrations were low $(<5.0 \mu \mathrm{g} / \mathrm{L})$ and total phosphorous values below $50 \mathrm{mg} / \mathrm{L}$, suggesting phosphorus limitation in most environments. On the other hand, the waters were rich in soluble reactive silica (above $180 \mu \mathrm{g} / \mathrm{L}$ in some environments), due to the predominant quartzite soil in that region (Table 2). 
Table 2 - Mean \pm standard deviation of the water physical and chemical parameters measured in the Doce River and São Francisco River watersheds, during the rainy and dry periods of 1998.

\begin{tabular}{lcccc}
\hline \multicolumn{1}{c}{ Parameters } & \multicolumn{2}{c}{ Doce river Watershed } & \multicolumn{2}{c}{ São Francisco river Watershed } \\
& Rainy & Dry & Rainy & Dry \\
Temperature $\left({ }^{\circ} \mathrm{C}\right)$ & $26.5 \pm 1.85$ & $21.63 \pm 0.46$ & $16.40 \pm 2.12$ & $14.77 \pm 3.20$ \\
$\mathrm{pH}$ & $6.69 \pm 1.07$ & $5.18 \pm 0.04$ & $7.08 \pm 0.30$ & $5.74 \pm 0.36$ \\
Elect. Conduct. $\left(\mu \mathrm{S} \mathrm{cm}^{-1}\right)$ & $14.32 \pm 6.72$ & $16.63 \pm 3.23$ & $45.10 \pm 31.54$ & $35.70 \pm 22.34$ \\
Dissolved Oxygen $\left(\mathrm{mg} \mathrm{l}^{-1}\right)$ & $7.48 \pm 2.37$ & $7.66 \pm 0.86$ & $5.26 \pm 0.03$ & $6.83 \pm 0.50$ \\
Total Alkalinity $\left(\mathrm{meqLCO}_{2}{ }^{-1}\right)$ & $48.3 \pm 9.6$ & $50.03 \pm 26.3$ & $148.45 \pm 113.1$ & $246.5 \pm 160.2$ \\
$\mathrm{SiO}_{2}\left(\mathrm{mgL}^{-1}\right)$ & $0.19 \pm 0.13$ & $0.03 \pm 0.05$ & $0.88 \pm 0.98$ & $0.09 \pm 0.57$ \\
$\mathrm{NO}_{2}^{-}\left(\mu \mathrm{gL}^{-1}\right)$ & $1.49 \pm 0.79$ & $3.23 \pm 0.42$ & $3.97 \pm 1.03$ & $1.51 \pm 0.57$ \\
$\mathrm{NO}_{3}^{-}\left(\mu \mathrm{gL}^{-1}\right)$ & $50.89 \pm 8.08$ & $235.1 \pm 109.8$ & $49.56 \pm 25.62$ & $179.42 \pm 64.77$ \\
$\mathrm{NH}_{4}^{+}\left(\mu \mathrm{gL}^{-1}\right)$ & $35.90 \pm 24.45$ & $35.5 \pm 6.31$ & $20.74 \pm 15.07$ & $30.70 \pm 9.07$ \\
$\mathrm{Total}_{-} \mathrm{N}\left(\mu \mathrm{gL}^{-1}\right)$ & $309.2 \pm 215.7$ & $651.5 \pm 403.6$ & $751.37 \pm 6.19$ & $312.05 \pm 32.61$ \\
$\mathrm{PO}_{4}^{-3}\left(\mu \mathrm{gl}^{-1}\right)$ & $1.88 \pm 2.54$ & $1.01 \pm 0.52$ & $1.62 \pm 1.40$ & $0.26 \pm 0.44$ \\
Total-P $\left(\mu \mathrm{gL}^{-1}\right)$ & $8.84 \pm 6.75$ & $27.03 \pm 19.55$ & $11.81 \pm 5.78$ & $3.87 \pm 1.33$ \\
\hline
\end{tabular}

Diversity, structure and composition of mayfly assemblages

A total of 3,249 nymphs were identified in the rainy season and 2,280 nymphs in the dry season in the Doce River watershed, distributed in 22 genera and 4 families (Appendix 1 and 2).

Baetidae was the dominant family in the two sampling periods at Doce river watershed, representing $94.5 \%$ (rainy season) and $70.9 \%$ (dry season) of the total abundance. The dominant genera in the watershed, in both sampling periods were Americabaetis ( $43.6 \%$ in the rainy and $26.4 \%$ in the dry period) and Rivudiva (36.3\% in the rainy, and $30.7 \%$ in the dry periods).

In the São Francisco River watershed, 744 nymphs were found in the rainy season, and 793 in the dry season, belonging to 22 genera and 5 families (Appendix 1 and 2). The dominant families in the rainy season were Leptophlebiidae (53.5\%) and Leptohyphidae $(39.5 \%)$, while in the dry season, Baetidae (43.88\%) and Leptohyphidae (36.95\%) were dominant. Leptohyphes was the dominant genus in both sampling periods $(39.4 \%$ in the rainy season and $36.95 \%$ in the dry period), followed by Hagenulus (25.54\% in the rainy period), and Americabaetis (29.13\% in the dry period).

In the rainy period, the São Francisco river watershed showed higher taxonomic richness, diversity and evenness of mayfly assemblages than the Doce river watershed in the rainy period (Fig. 1). Besides that, the $t$ tests revealed that the Shannon-Wiener diversity $\quad\left(\mathrm{t}_{(10 ; 0.05)}=-1.77779\right.$; $\mathrm{p}=0.1058)$ and total density $\left(\mathrm{t}_{(10 ; 0.05)}=0.70710\right.$; $\mathrm{p}=0.4957$ ) were not significantly different between the two studied watersheds. The Mann-Whitney U Test also revealed that the taxonomic richness $(\mathrm{U}=13,5 ; \mathrm{p}=0,66894)$ was not different between the Doce River and São Francisco River watersheds. On the other hand, significant differences $\left(\mathrm{t}_{(10 ; 0.05)}=2.38091 ; \mathrm{p}<0.05\right)$ were found for the evenness values. 
Appendix 1 - Mayfly assemblage composition, total density (ind $/ \mathrm{m}^{2}$ ), $\mathrm{H}^{\prime}$ Shannon-Wiener, taxonomic richness and $J^{\prime}$ Pielou in the sampling stations (\#) in Doce River and São Francisco River watersheds, during the rainy period of 1998.

\begin{tabular}{|c|c|c|c|c|c|c|c|c|}
\hline & & & & Doce River & & & & São Francisco River \\
\hline Taxa & \#1A & \#1B & $\# 2 \mathrm{~A}$ & \#2B \#2C & \#4A & \#4B & \#4C & \#5A \#5B \#6A \#6B \\
\hline
\end{tabular}

\section{Baetidae}

$\begin{array}{rrr}\text { Americabaetis } & 1 & 1237 \\ \text { Apobaetis fiuzai } & & \\ \text { Aturbina georgei } & & 7 \\ \text { Baetodes } & 1 & 18 \\ \text { Camelobaetidius } & 1 & 117 \\ \text { Cloeodes } & 1 & 17 \\ \text { Paracloeodes } & 2 & \\ \text { Callibaetis } & & \end{array}$

Waltzoyphius fasciatus

Leptohyphidae

Tricorythopsis

Leptohyphes

Tricorythodes

48

3

$229 \quad 5$

$\begin{array}{lll}98 & 77 & 3 \\ 9 & & 1 \\ 2 & & 4\end{array}$

18

117

17

1

6

$852 \quad 251$

4
28

19

3

$\begin{array}{cc} & 1 \\ 41 & 27 \\ & \\ & 3 \\ 3 & 5 \\ 2 & 10\end{array}$

$11 \quad 1$

$\begin{array}{llll}27 & 3 & 6 & 2\end{array}$

\section{Caenidae}

Caenis

\section{Polymitarcyidae}

$\begin{array}{lccc}\text { Asthenopus } & 1 & & 1 \\ \text { Campsurus } & & 1 & \end{array}$

\section{Oligoneuriidae}

Oligoneuriinae

1

\section{Leptophlebiidae}

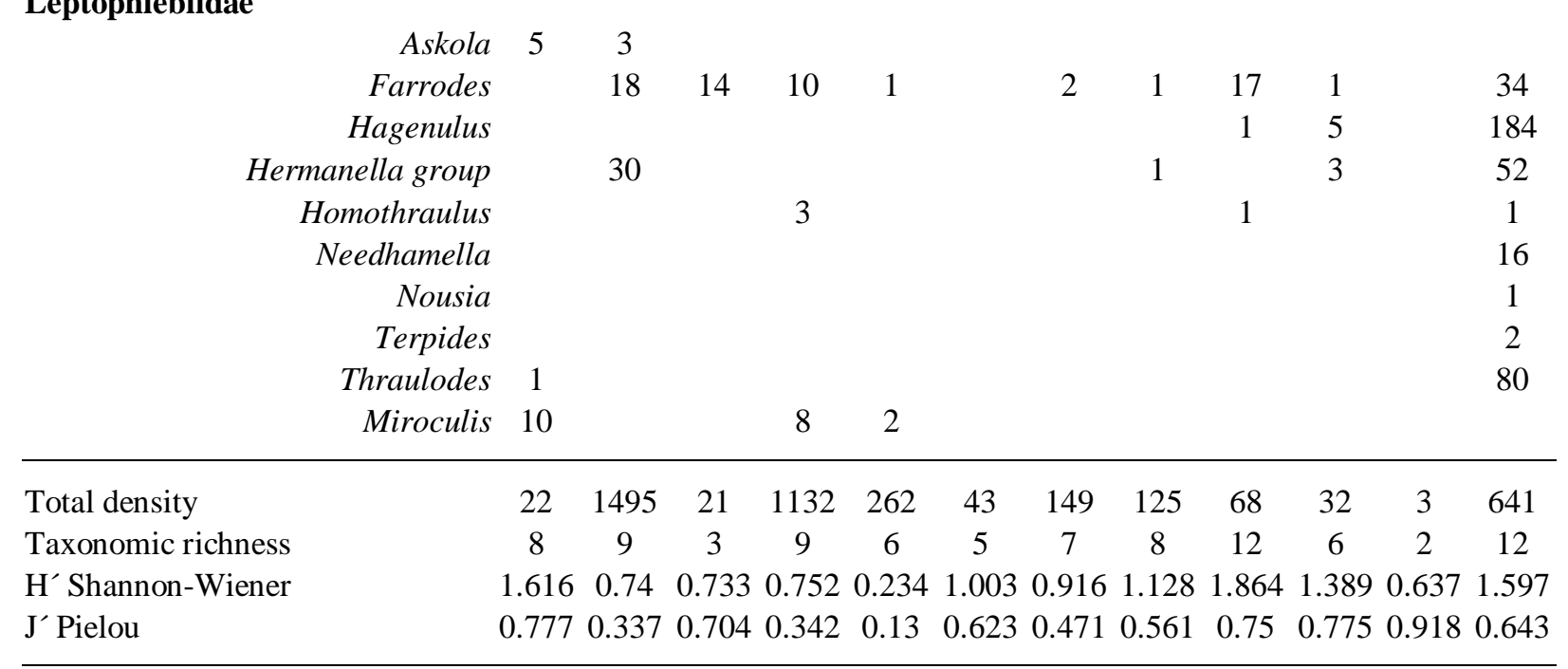


Appendix 2 - Mayfly assemblage composition, total density (ind $/ \mathrm{m}^{2}$ ), $\mathrm{H}^{\prime}$ Shannon-Wiener, taxonomic richness and $J^{\prime}$ Pielou in the sampling stations (\#) in Doce River and São Francisco River watersheds, during the dry period of 1998.

\begin{tabular}{|c|c|c|c|c|c|c|c|c|c|c|c|c|}
\hline \multirow[b]{2}{*}{ Taxa } & \multirow[b]{2}{*}{$\# 2 \mathrm{~A}$} & \multirow[b]{2}{*}{ \#2B } & \multicolumn{2}{|c|}{ Doce River } & \multirow[b]{2}{*}{ \#4A } & \multicolumn{4}{|c|}{ São Francisco River } & \multirow[b]{2}{*}{ \#7A } & \multirow[b]{2}{*}{ \#7B } & \multirow[b]{2}{*}{$\# 7 \mathrm{C}$} \\
\hline & & & $\# 3 \mathrm{~A}$ & \#3B & & \#4B & $\# 5 \mathrm{~A}$ & $\# 5 \mathrm{~B}$ & \#6A & & & \\
\hline \multicolumn{13}{|l|}{ Baetidae } \\
\hline Americabaetis & & 7 & 145 & 437 & & 12 & 5 & & 94 & 7 & 16 & 101 \\
\hline Apobaetis fiuzai & 1 & 1 & & & & & & 3 & & & & \\
\hline Aturbina georgei & 12 & 19 & & & & 12 & & & & 10 & & \\
\hline Baetodes & & & 4 & & & & & & & & & \\
\hline Camelobaetidius & 2 & & 46 & & & & 2 & & 64 & & & \\
\hline Cloeodes & 8 & 3 & 48 & & 8 & & & 3 & 2 & 2 & 2 & \\
\hline Moribaetis & & & & & & & & & & 2 & & \\
\hline Paracloeodes & 3 & 522 & & 20 & 7 & 149 & & 17 & & & & \\
\hline Callibaetis & 67 & 1 & & & 43 & 4 & & 16 & & & & \\
\hline Waltzoyphius fasciatus & & & & 36 & 1 & & 2 & & & & & \\
\hline \multicolumn{13}{|l|}{ Leptohyphidae } \\
\hline Tricorythopsis & 3 & & 112 & 3 & & 1 & & & & & & \\
\hline Leptohyphes & 4 & & 133 & 89 & 2 & 4 & 31 & 65 & 149 & 25 & 20 & 3 \\
\hline Tricorythodes & & 5 & & & 1 & 1 & & & & & & \\
\hline \multicolumn{13}{|l|}{ Caenidae } \\
\hline Caenis & & & & & & & & 1 & & 16 & & \\
\hline \multicolumn{13}{|l|}{ Leptophlebiidae } \\
\hline Askola & & & & & & & & & & 1 & 1 & \\
\hline Farrodes & & 15 & 9 & 83 & & 7 & 14 & & 43 & 2 & 2 & 2 \\
\hline Hagenulus & & & 63 & 75 & & & & & 8 & & & \\
\hline Hermanella group & & & 26 & 1 & & & 2 & & 6 & & & \\
\hline Homothraulus & & 4 & & & & 6 & & & & & & \\
\hline Needhamella & & & & & & & & & 2 & & & \\
\hline Nousia & & & 4 & & & & & & & & & \\
\hline Thraulodes & & 1 & 10 & & & & & & 2 & & & \\
\hline Miroculis & & & & & & & & & & 50 & & \\
\hline Total density & 100 & 578 & 600 & 744 & 62 & 196 & 56 & 105 & 370 & 115 & 41 & 106 \\
\hline Taxonomic richness & 8 & 10 & 11 & 8 & 8 & 9 & 6 & 6 & 9 & 9 & 5 & 3 \\
\hline $\mathrm{H}^{\prime}$ Shannon-Wiener & 1.188 & 0.488 & 1.96 & 1.317 & 1.008 & 0.989 & 1.247 & 1.126 & 1.502 & 1.604 & 1.103 & 0.222 \\
\hline $\mathrm{J}^{\prime}$ Pielou & 0.571 & 0.212 & 0.817 & 0.634 & 0.563 & 0.45 & 0.696 & 0.628 & 0.684 & 0.73 & 0.685 & 0.202 \\
\hline
\end{tabular}



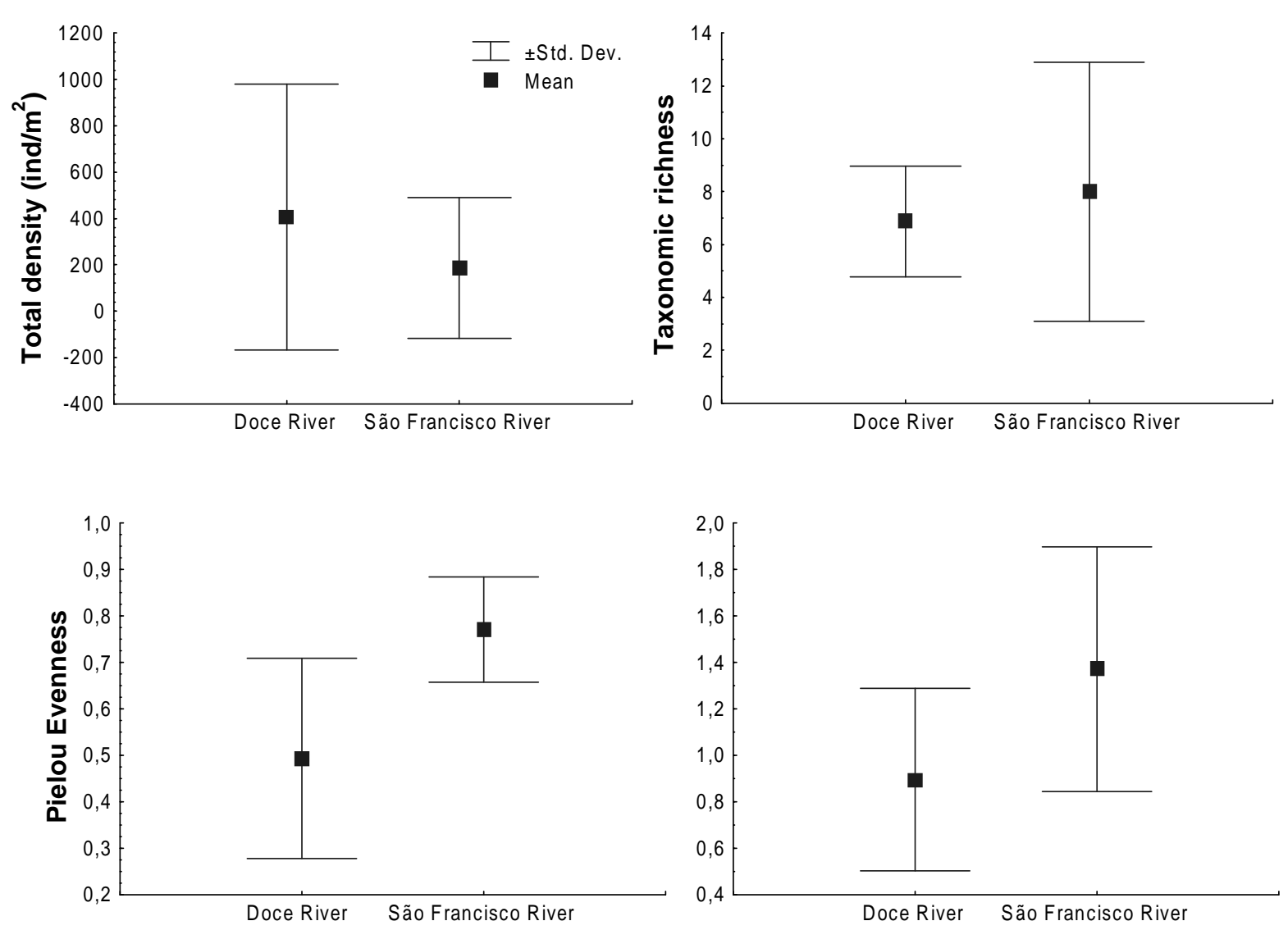

Figure 1 - Total density (ind $/ \mathrm{m}^{2}$ ), taxonomic richness, Pielou evenness and Shannon-Wiener diversity of mayfly assemblages during the rainy period of 1998 in Doce River and São Francisco River watersheds (Serra do Cipó, Brazil).

In the dry period, the Doce river watershed showed higher taxonomic richness than the São Francisco river watershed, and narrow differences in diversity and evenness between the Doce river and São Francisco river watersheds were noted (Fig. 2). The $\mathrm{t}$ tests revealed no significant differences in the taxonomic richness $\left(\mathrm{t}_{(10 ; 0.05)}=\right.$ 1.95656; $\mathrm{p}=0.0789$ ), Shannon-Wiener diversity $\left(\mathrm{t}_{(10 ; 0.05)}=0.17387 ; \quad \mathrm{p}=0.8654\right), \quad$ and evenness

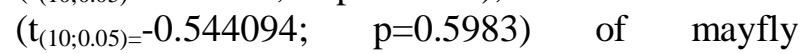
assemblages between the Doce river and São Francisco river watersheds. The Mann-Whitney U test revealed that the differences in the total density values $(U=9 ; p=0.149551)$ were not statistically significant. In both periods, the total density of mayfly assemblages was higher in the Doce river watershed (Appendix 1 and 2). 

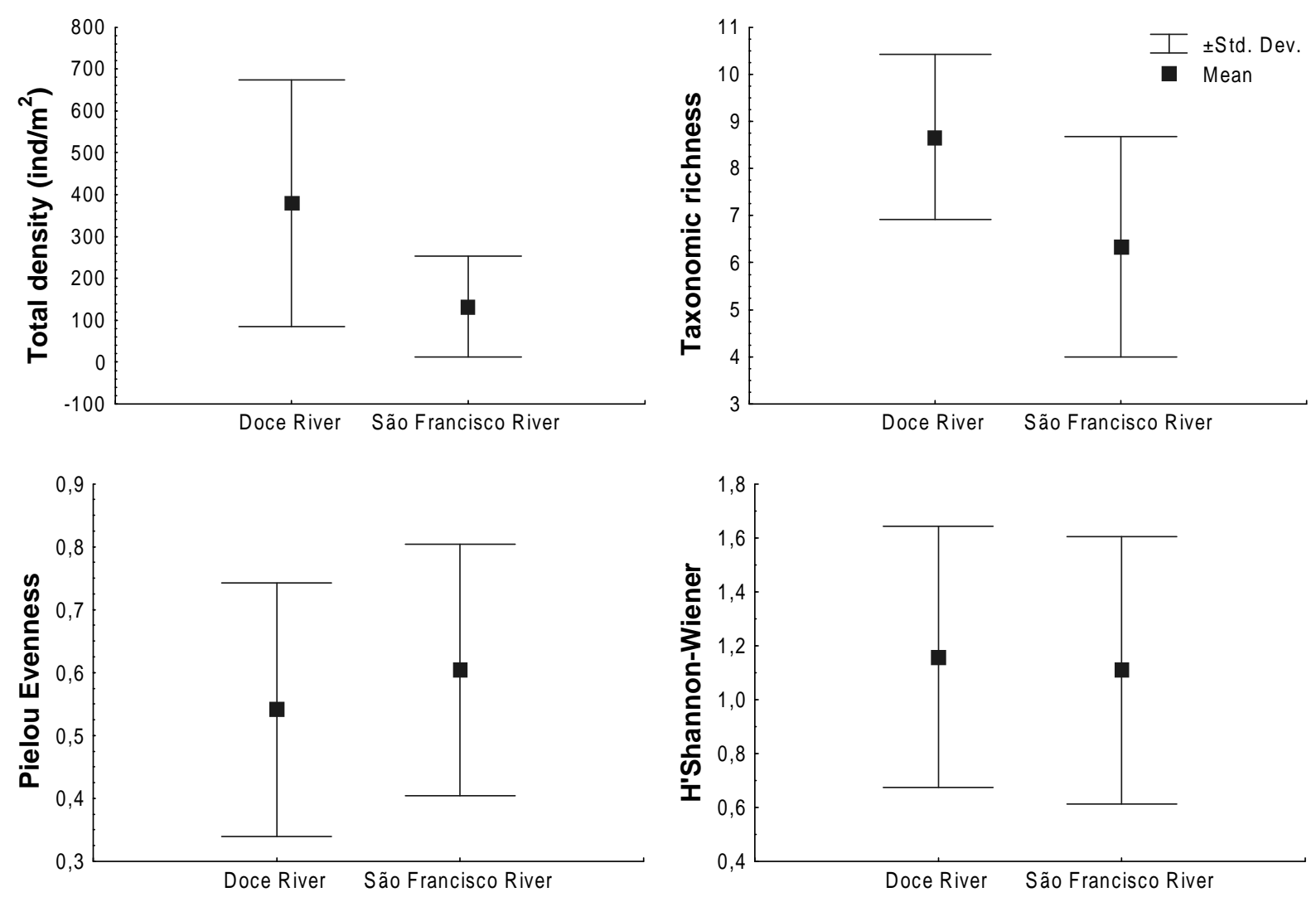

Figure 2 - Total density $\left(\mathrm{ind} / \mathrm{m}^{2}\right.$ ), taxonomic richness, Pielou evenness and Shannon-Wiener diversity of mayfly assemblages during the dry period of 1998 in Doce River and São Francisco River watersheds (Serra do Cipó, Brazil).

No significant differences were found between the two sampling periods for taxonomic richness $\left(\mathrm{t}_{(22 ; 0.05)}=-0.22344 ; \quad \mathrm{p}=0,82526\right), \quad \mathrm{H}^{\prime}$ ShannonWiener diversity $\left(\mathrm{t}_{(22 ; 0.05)}=-0,41234 ; \mathrm{p}=0,68408\right)$, J'Pielou $\left(\mathrm{t}_{(22 ; 0.05)}=0,15336 ; \mathrm{p}=0,87951\right)$, or total density $(U=61 ; p=0,52538)$. In the rainy period, higher values were found for total density and evenness, while in the dry period, the taxonomic richness and $\mathrm{H}^{\prime}$ Shannon-Wiener diversity were higher (Appendix 1 and 2).

\section{Substrate associations of mayfly nymphs}

Most of the identified mayfly taxa were associated to 3 or 4 kinds of substrates (e.g., Aturbina georgei Lugo-Ortiz and McCafferty); some were found in only 1 or 2 kinds of substrates (e.g. Terpides, unidentified Oligoneuriinae), while others showed a broad distribution, being presente in over 5 from all sampled substrates (e g., Leptohyphes, Americabaetis). Even the generalist genera seemed to have preference for the substrate type, usually presenting high densities in only 2 or 3 substrates (Table 3). Some substrates presented high taxonomic richness as the submerged leaves and branches of riparian vegetation, where almost all identified genera were found with some of them presenting exclusive distribution or higher densities (Fig. 3). This substrate was found in Peixe (near its confluence with Preto do Itambé river), Preto do Itambé and Cipó rivers. Several identified taxa showed preference for this substrate. 


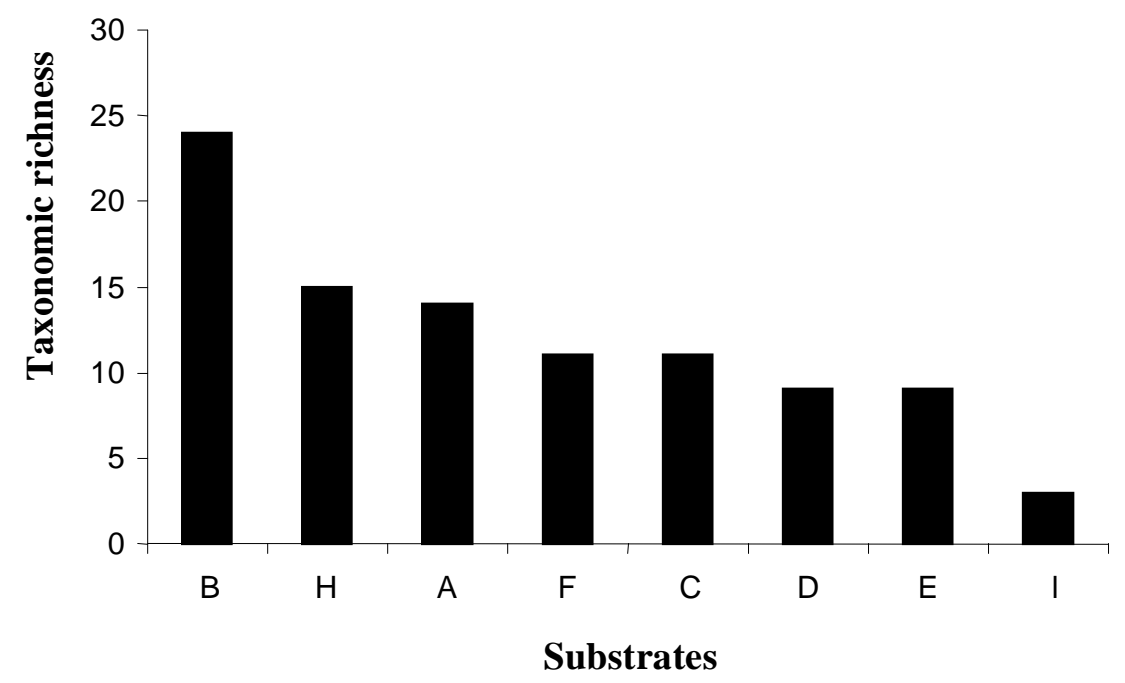

Figure 3 - Taxonomic richness of mayfly in the sampled substrates (legends as in Table 3).

Paracloeodes, in spite of been found in 6 of the 9 sampled substrates, presented over $82 \%$ of its total abundance associated with riparian vegetation. Others also showed substrate preferences, such as Aturbina georgei Lugo-Ortiz and McCafferty, Apobaetis fiuzai Salles and Lugo-Ortiz, 2002, Waltzoyphius fasciatus McCafferty and LugoOrtiz, Leptohyphes, Farrodes, Hermanella group, Hagenulus and Thraulodes (Table 3). Americabaetis was found in most of the sampled substrates, and often constituted the taxon wit highest densities associated with aquatic macrophytes, such as filamentous algae in the São Francisco river watershed, and mosses and angiosperms in the Doce river watershed. On the other hand, some genera were found typically associated with the presence of algal biofilm over rock substrates (e. g., Tricorythopsis and Cloeodes), or vegetal substrates (e. g., Thraulodes and Camelobaetidius). Hermanella, Needhamella and Hagenulus were found associated to the aquatic vegetation (such as macrophytes, mosses or riparian vegetation) and rock substrates. The poorer substrate for mayfly nymphs was the filamentous algae, found in Capão da Mata stream (Fig. 3). Only Americabaetis, Leptohyphes and Farrodes, commonly present in all sampled substrate, were found in that substrate type (Table 3).

\section{DISCUSSION}

Diversity, structure and composition of mayfly assemblages

The aquatic ecosystems studied in the Doce River watershed showed higher temperatures than those of São Francisco river watershed (Galdean et al., 2000; Callisto et al., 2001b; Galdean et al., 2001). Apparently, the higher temperatures favored the densities and diversity of Baetidae genera in the Doce River watershed, reflected by the lower evenness values found in this watershed. According to Zamora-Muñoz et al. (1993), temperature is one of the major factors determining the distribution of Baetidae, most of the species with higher densities in warmer waters. Characteristic invertebrate assemblages in rivers are often associated with a given landscape formation, and the species diversity occur in function of evolutionary history of the biome and land use adjacent to the river channel (Corkum, 1991). The Doce river and São Francisco river watersheds are in two zones with strong and complex differences of soil and climate, also presenting different geomorphologic origin. Most of the Doce river watershed is located in the Espinhaço Mountainous Geosystem, while the São Francisco river watershed has most of its tributaries within the Cipó River Inter-Plateau Semi-Mountainous Zone (Ab'Saber, 1990). Besides that their upper reaches are similar, with the headwaters (such as Indaiá and Capão da Mata 
streams) being in rupestrian fields and middle reaches (e. g., Cipó and Peixe rivers) located inside farms and receiving the same impacts from anthropogenic influence. This fact might explain, in part, the absence of significant differences in taxonomic richness and diversity of mayfly assemblages between the studied watersheds.

Table 3 - Abundance of mayfly nymphs in the sampled substrates in Serra do Cipó studied ecosystems, during rainy and dry periods of 1998. *A=deposit of detritus; $\mathrm{B}=$ leaves and branches of riparian vegetation; $\mathrm{C}=$ leaf litter/debris; $\mathrm{D}=$ submerged angiosperms; $\mathrm{E}=$ banks of mosses and angiosperms; $\mathrm{F}=$ stones with periphytic algae; $\mathrm{G}=$ pebbles and gravel; $\mathrm{H}=$ gravel and fine sediments; I=tufts of filamentous algae.

\begin{tabular}{|c|c|c|c|c|c|c|c|c|c|}
\hline Taxa & $\mathbf{A}$ & B & $\mathrm{C}$ & D & $\mathbf{E}$ & $\mathbf{F}$ & G & H & $\mathbf{I}$ \\
\hline \multicolumn{10}{|l|}{ Baetidae } \\
\hline Americabaetis & 0.71 & 5.92 & 0.31 & 22.86 & 55.03 & 6.45 & 4.18 & 0.04 & 4.49 \\
\hline Apobaetis fiuzai & 66.67 & 13.33 & & & & & & 20.0 & \\
\hline Aturbina georgei & 4.0 & 88.7 & 5.0 & & 2.3 & & & & \\
\hline Baetodes & & 11.54 & & & 69.23 & 15.38 & & 3.85 & \\
\hline Callibaetis & 87.27 & 3.03 & & & & & & 9.7 & \\
\hline Camelobaetidius & 0.82 & 5.33 & & & 47.95 & 18.85 & 26.23 & 0.82 & \\
\hline Cloeodes & 18.56 & 5.15 & 2.06 & 1.03 & 17.53 & 49.49 & 2.06 & 4.12 & \\
\hline Moribaetis & & & 100.0 & & & & & & \\
\hline Paracloeodes & 0.78 & 82.26 & 13.11 & 2.45 & & & 0.1 & 1.3 & \\
\hline Waltzoyphius fasciatus & 1.64 & 34.43 & & 63.93 & & & & & \\
\hline \multicolumn{10}{|l|}{ Caenidae } \\
\hline Caenis & & 5.56 & 88.89 & & & & & 5.56 & \\
\hline \multicolumn{10}{|l|}{ Leptohyphidae } \\
\hline Tricorythopsis & 2.34 & 3.91 & & 6.25 & & 87.5 & & & \\
\hline Leptohyphes & 2.93 & 36.19 & 3.04 & 11.16 & 5.41 & 14.99 & 16.8 & 9.13 & 0.34 \\
\hline Tricorythodes & 22.22 & 66.67 & & & & & 11.11 & & \\
\hline \multicolumn{10}{|l|}{ Leptophlebiidae } \\
\hline Askola & 10.0 & & 10.0 & & 30.0 & & & 50.0 & \\
\hline Farrodes & 5.82 & 36.0 & 1.09 & 30.55 & 6.55 & 3.27 & 15.64 & 0.36 & 0.73 \\
\hline Hagenulus & & 55.06 & & 22.32 & & 18.75 & 2.38 & 1.49 & \\
\hline Hermanella group & & 44.63 & & 1.65 & 24.79 & 21.49 & 4.96 & 2.48 & \\
\hline Homothraulus & & 100.0 & & & & & & & \\
\hline Needhamella & & 88.89 & & & & & 11.11 & & \\
\hline Nousia & & 20.0 & & & & 80.0 & & & \\
\hline Terpides & & 100.0 & & & & & & & \\
\hline Thraulodes & & 86.17 & & & & 10.64 & 2.13 & 1.06 & \\
\hline Miroculis & & 11.43 & 74.29 & & & & & 14.29 & \\
\hline \multicolumn{10}{|l|}{ Oligoneuriidae } \\
\hline Oligoneuriinae & & 100.0 & & & & & & & \\
\hline \multicolumn{10}{|l|}{ Polymitarcyidae } \\
\hline Asthenopus & & 50.0 & 50.0 & & & & & & \\
\hline Campsurus & 100.0 & & & & & & & & \\
\hline
\end{tabular}

capacity; second, association with specific substrates; and third, deficient sampling effort.

The obtained results showed that some taxa were found in only one of the two studied watersheds. We assumed that this difference was possibly due to three reasons: first, the isolation due to dispersal
The capability for drifting dispersal of the mayfly nymphs made the mayflies good colonizers. In spite of this fact, their dispersal capacity over long distances is limited, due to the fragile nature and 
short life of the adults (Brittain, 1982). Thus, some groups may become isolated, so that some of the differences in the composition of the assemblages may be in part explained. The second possible reason refers to the association of mayflies and the substrates. For example, Tricorythopsis was found strongly associated with the substrate composed by stones with periphytic algae, which was not present in the São Francisco river watershed ecosystems. The third possibility refers to the sampling effort.

\section{Substrate diversity, habitat diversity and mayfly assemblages}

Substrate is a major factor governing the distribution and diversity of aquatic macroinvertebrates (Allan, 1995). Most species are restricted or more abundant in few (2 or 3 ) rather than several kinds of substrate (Ward, 1992). Most of the genera here were found associated or presented higher densities in one to three types of substrate.

The diversity of habitats and microhabitats in lotic ecosystems is due to high diversity of substrates and the heterogeneity of the sediment (Ward, 1992). Colonization patches are formed along the channel of the river, from one margin to another, providing a wide range of situations and ecological niches (Death and Winterbourn, 1995). We were able to detect this situation in the Peixe river (locality of Sobrado Farm), where we found high diversity of habitats and microhabitats. This high diversity is probably due to the heterogeneity of the river bottom and diversity of the aquatic vegetation, which support physical substrate and indirect source of food (surface for growing of periphytic communities), and trapping organic particles. The mayfly assemblages responded to this situation presenting the highest values of diversity and taxonomic richness for this watershed. On the other hand, rivers that presented low heterogeneity of the sediment, with large deposits of sand and silt, and no aquatic vegetation, presented the lowest values of diversity and taxonomic richness.

The availability of trophic resources is one of the most important factors that determine the distribution and abundance of lotic invertebrates (Callisto et al., 2001b). The trophic resources may vary with watershed conformation (e.g., covering of river bed by riparian vegetation), stream order, season and anthropogenic influence (Vannote et al., 1980; Allan, 1995; Callisto et al., 2001b).
Generally, the abundance of a specific trophic resource will determine the composition (thus diversity) and abundance of macroinvertebrate communities (Ward, 1992). Mayfly nymphs are generally opportunistic feeders that feed on a wide range of food resources available in the environment, with most of the species being collectors (filtering and gathering) or scrapers and only a few species being true carnivorous (e. g., Harpagobaetis gulososos, Baetidae) (Brittain, 1982; Edmunds and Waltz, 1998; Pescador, 1997). In function of the prevailing trophic resource, the species composition in a determinate ecosystem may vary considerably (Ward, 1992). In Serra do Cipó, shallow rivers with low organic load and sediment composed by rocks, pebbles, and other coarse sediment particles (e. g., Peixe river, Sobrado Farm) favored the development of primary producers, specially periphytic algae, which enhanced the mayfly assemblages with scrapers, such as Thraulodes and Baetodes. On the other hand, rivers that received larger loads of organic particles, favored the presence of filteringcollectors mayflies, such as the Hermanella group, and Hagenulus as in Cipó River. Their presence probably is closely related to the quantity and quality of suspended fine particulate organic matter (Galdean et al., 1999).

These results showed that the mayflies were a diverse and abundant component in the headwaters of Doce and São Francisco rivers in Serra do Cipó, presenting high taxonomic richness and welldefined and structured assemblages. We consider that the diversity of mayfly assemblages is probably resultant from three major factors: ecosystem characteristics, such as substrate type and habitat diversity; watershed characteristics, such as canopy cover over the river channels and use and occupancy of the watershed (reflecting in the availability of trophic resources and abiotic features, such as water temperature); historical past of colonization, provoking the isolation of some groups. Besides that we must point out that further intensive collections enlarging the sampling designs, and over longer periods of time, are necessary to clarify some of the differences observed in the mayfly diversity.

Due to the fact that mayfly assemblages reflect some of the main aspects of the conservation of natural characteristics of the altitudinal headwaters, we propose, as suggested by other authors (e. g., Buffagnani, 2001) the use of Ephemeroptera as indicators of conservation status 
of biological quality of streams. Coupled with the evaluation of ecological characteristics of the studied watersheds, the assessment of mayfly diversity should be included in monitoring programs of tropical headwaters.

\section{ACKNOWLEDGMENTS}

The authors are especially grateful to MSc F. F. Salles for the confirmation of Baetidae taxa, and language review by Mr. L. Cota. The logistic support offered by IBAMA, financial support by Brazilian Research Council (CNPq) ( $\mathrm{n}^{\circ}$. 462185/00-1, 472328/01-8) and Fundação de Amparo à Pesquisa do Estado de Minas Gerais (FAPEMIG) ( $n^{\circ}$. CRA-123497), and CAPES for scholarship funds are appreciated.

\section{RESUMO}

Os objetivos foram avaliar a distribuição espaçotemporal, estrutura de assembléias e associações de ninfas de Ephemeroptera com substratos em 5 ecossistemas lóticos nas nascentes das bacias dos rios Doce e São Francisco, Brasil. As amostragens foram realizadas em 24 estações, nos períodos de chuvas e seca de 1998. No total, 7,066 organismos foram coletados, pertencentes a 27 gêneros e 6 famílias. Os taxa dominantes foram Americabaetis, Paracloeodes, Leptohyphes e Hagenulus. No período de chuvas foram observados maiores valores dos indices de riqueza taxonômica, diversidade e equitabilidade na bacia do rio São Francisco, enquanto que no período de seca, a riqueza taxonômica foi maior na bacia do rio Doce. Não foram encontradas diferenças significativas dos valores dos indices de riqueza, equitabilidade, diversidade e densidade de ninfas de Ephemeroptera entre os dois períodos estudados. Os resultados obtidos sugerem que a diversidade das assembléias de Ephemeroptera nas cabeceiras da Serra do Cipó são provavelmente devido a características ecológicas dos ecossistemas aquáticos e bacias hidrográficas estudadas.

\section{REFERENCES}

Ab'Saber, A. B. (1990), Paleoclimas quaternários e préhistória da América Tropical. II. Braz. J. Biol., 50, 821-831.

Alba-Tercedor, J. (1996) Macroinvertebrados acuaticos y calidad de las aguas de los rios. IV Simposio del Agua em Andalucia, 2, 203-213.

Allan, J. D. (1995), Stream ecology: structure and function of running waters. New York: Chapman and Hall.

Bispo, P. C. and Oliveira, L. G. (1998), Distribuição espacial de insetos aquáticos (Ephemeroptera, Plecoptera e Trichoptera) em córregos de Cerrado do Parque Ecológico de Goiânia, Estado de Goiás. Oeocologia Brasiliensis, 5, 19-33.

Brittain, J. E. (1982), Biology of Mayflies. Ann. Rev. Entomol., 27, 119-47.

Buffagnani, A. (2001), Mayfly community composition and the biological quality of streams. In: Landolt, P. and Sartori, M. (Eds.). Ephemeroptera and Plecoptera. Fribourg: MTL. v. 1. pp. 235-246.

Callisto, M. F. P. and Esteves, F. A. (1995), Distribuição de macroinvertebrados bentônicos em um ecossistema impactado por rejeito de bauxita (Pará, Brasil). Oecologia Brasiliensis, 1, 335-348.

Callisto, M.; Moretti, M. and Goulart, M. (2001a), Macroinvertebrados bentônicos com ferramenta para avaliar a saúde de riachos. Revta. Bras. Rec. Hid., 6, 71-82.

Callisto, M.; Moreno, P. and Barbosa, F. A. R. (2001b), Habitat diversity and benthic trophic functional groups at Serra do Cipó, southeast Brazil. Braz. J. Biol., 61, 259-266.

Carmouze, J. P. (1994), O metabolismo dos ecossistemas aquáticos: fundamentos teóricos, métodos de estudo e análises químicas. São Paulo: Edgard Blücher; FAPESP.

CETEC (1982), Principais atividades realizadas para a implantação do Parque Estadual da Serra do Cipó. Unpublished technical report. Belo Horizonte: CETEC.

Corkum, L. D. (1991), Spatial patterns of macroinvertebrate distributions along rivers in eastern deciduous forest and grassland biomes. J. N. Am. Benthol. Soc., 10, 358-371.

Death, R. G. and Winterbourn, M. J. (1995), Diversity patterns in stream invertebrate communities - the influence of habitat stability. Ecology, 76, 1446-1460.

Domínguez, E.; Hubbard, M. D. and Peters, W. L. (1992), Clave para ninfas y adultos de las familias y géneros de Ephemeroptera (Insecta) sudamericanos. Biologia Acuatica, 16, 1-39.

Domínguez, E. and Pescador, M. L. (1994), Los Ephemeroptera en Argentina. Fauna de Agua Dulce de la Republica Argentina, 33, 1-142. 
Domínguez, E.; Hubbard, M. D.; Pescador, M. L. and Molineri, C. (2001), Ephemeroptera. In: Fernández, H. R. and Dominguez, E. (Eds.). Guía para la determinación de los artrópodos bentónicos sudamericanos. Argentina: Universidad Nacional de Tucumán. pp. 17-54.

Edmunds Jr., G. F. and Waltz, R. D. (1998), Ephemeroptera. In: Merrit, R. W. and Cummins, K. W. (Eds.). An Introduction to the Aquatic Insects of North America. $3^{\text {rd }}$ ed. New York: Kendall-Hunt. pp. 126-163.

Ferreira, M. S. N. and Froehlich, C. G. (1992), Estudo da fauna de Ephemeroptera (Insecta) do Córrego do Pedregulho (Pedregulho, SP, Brasil) com aspectos da biologia de Thraulodes schlingeri Traver and Edmunds, 1967. Rev. Bras. Ent., 36, 541-548.

Froehlich, C. G. and Oliveira, L. G. (1997), Ephemeroptera and Plecoptera nymphs from riffles in low-order streams in southeastern Brazil. In: Landolt, P. and Sartori, M. (Eds.). Ephemeroptera and Plecoptera: Biology-Ecology-Systematics. Fribourg: MTL. v. 1. pp. 180-185.

Fundação Estadual do Meio Ambiente (1990), Projeto Rio Doce. Unpublished technical report. Belo Horizonte: FEAM.

Galdean, N.; Barbosa, F. A. R.; Callisto, M.; Rocha, L. A. R. and Marques, M. G. S. M. (1999), A proposed typology for the rivers of Serra do Cipó (Minas Gerais, Brazil) based on the diversity of benthic macroinvertebrates and the existing habitats. Trav. Mus. Natl. Hist. Nat.Grigori Antipa, 41, 445-453.

Galdean, N.; Callisto, M.; and Barbosa, F. A. R. (2000), Lotic Ecosystems of Serra do Cipó, southeast Brazil: water quality and a tentative classification based on the benthic macroinvertebrate community. Aquatic Ecosystem Health and Management, 3, 545-552.

Galdean, N.; Callisto, M. and Barbosa, F. A. R. (2001), Biodiversity assessment of benthic macroinvertebrates in altitudinal lotic ecosystems of Serra do Cipó (MG - Brazil). Braz. J. Biol., 61, 239-248.

Galvão, M. V. and Nimer, E. (1965), Clima. In: Geografia do Brasil-Grande Região Leste. Rio de Janeiro: IBGE. v. 5. pp. 91-139.

Giulietti, A. M.; Menezes, N. A.; Pirani, J. R.; Meguro, M. and Vanderley, M. G. L. (1987), Flora da Serra do Cipó: caracterização e lista de espécies. Boletim de Botânica, 9, 1-151.

Golterman, H. L.; Clymo, R. S. and Ohnstad, M. A. M. (1978), Methods for chemical analysis of freshwaters. Blackwell Scientific Publications.

Governo Federal (1997), Sumário e Formulação do Programa Xingó. Unpublished technical report. Brasília: CNPq.

IBGE (2001), Sistematização das Informações sobre Recursos Naturais. Disp. in: http://www.ibge.gov.br/english/default.php.
Lugo-Ortiz, C. R. and McCafferty, W. P. (1995), Three distinctive new genera of Baetidae (Ephemeroptera) from South America. Annls. Limnol., 31, 233-243.

Lugo-Ortiz, C. R. and McCafferty, W. P. (1996a), Taxonomy of the Neotropical genus Americabaetis: new status (Insecta: Ephemeroptera: Baetidae) from South America. Stud. Neotrop Fauna and Environm., 31, 156-169.

Lugo-Ortiz, C. R. and McCafferty, W. P. (1996b), Aturbina georgei gen. et sp. n.: a small minnow mayfly (Ephemeroptera: Baetidae) without turbinate eyes. Aquatic. Insects., 18, 175-183.

Lugo-Ortiz, C. R. and McCafferty, W. P (1996c), The genus Paracloeodes (Insecta: Ephemeroptera: Baetidae) and its presence in South America. Annls. Limnol., 32, 161-169.

Mackereth, F. J. H.; Heron, J. and Talling, J. F. (1978), Water Analysis: some revised methods for limnologists. Windermere: Freshwater Biological Association.

Magurran, A. E. (1991), Ecological Diversity And its Measurement. $2^{\text {nd }}$ ed. London: Chapman and Hall.

Marques, M. M. and Barbosa, F. A. R. (2001), Biological quality of waters from an impacted tropical watershed (middle Rio Doce basin, southeast Brazil), using benthic macroinvertebrates as an indicator. Hydrobiologia, 457, 69-76.

Oliveira, L. G. and Froehlich, C. G. (1997), Diversity and community structure of aquatic insects (Ephemeroptera, Plecoptera and Trichoptera) in a mountain stream in southeastern Brazil. Acta Limnol. Bras., 9, 139-148.

Pescador, M. L. (1997), General Ecology of Mayflies: adaptations, reproductive strategies and trophic categories. In: Bioindicadores ambientales de calidad de agua, pp. 1-10. Universidad del Valle, Colombia.

Peters, W. L. (1971), A revision of the Leptophlebiidae of the West Indies (Ephemeroptera). Smithsonian Contributions to Zoology, 62, 1-48.

Salles, F. F. and Lugo-Ortiz, C. R. (2002), A distinctive new species of Apobaetis (Ephemeroptera: Baetidae) from Mato Grosso and Minas Gerais, Brazil. Zootaxa, 35, 1-6.

Vannote, L. R.; Minshall, G. W.; Cummins, K. W.; Sedell, J. R. and Cushing, C. E. (1980), The river continuum concept. Can. J. Fish. Aquat. Sci., 37, 130-137. 
Ward, J. V. (1992), Aquatic Insect Ecology: 1. Biology and habitat. New YorkL: John Wiley and Sons.

Ward, D.; Holmes, N. and José, P. (1995), The New Rivers and Wildlife Handbook. RSPP, NRA e The Wildlife Trusts, Bedfordshire.

Zamora-Muñoz, C.; Sanchez-Ortega, A. and AlbaTercedor, J. (1993), Physico-chemical factors that determine the distribution of mayflies and stoneflies in a high-mountain stream in Southern Europe (Sierra Nevada, Southern Spain). Aquatic Insects., 1, 11-20.

Received: April 15, 2004; Revised: August 17, 2004; Accepted: May 23, 2005. 